\title{
Comparative Law Analysis of Consumer Protection Law in E-Commerce Transaction Between Indonesia and United States
}

\author{
Felix Pratama Tjipto \\ International Business Law, Universitas Prasetiya Mulya, Indonesia. Email: pratama.felix8@gmail.com
}

\begin{abstract}
Innovation of technology and rapid growth of digitalization is steadily increasing its capacity in supporting human daily tasks, one of which is through online transactions that are increasing rapidly due to the occurrence of COVID-19 pandemic which forces people to do their activities from home. Nevertheless, the increased usage of technology directly affects the rise in creating loopholes and abuse of power which may violate the regulations and consumer's rights in doing online transactions. This paper shall discuss and provide comparative and statute approach analysis between Indonesian and U.S law, its creation methods, organizations involved and law enforcement since it is important to address this issue in order to ensure that the enforcement of a solid legal framework is really being applied to regulate this matter.
\end{abstract}

Keywords: consumer protection, consumer, right, regulation.

\section{Introduction}

Nowadays, the world of transactions is gradually transforming, as globalization, free trade and cross-border transactions are a natural thing in our life which transforms the flow and principle of transaction itself. Especially in Indonesia, digitalization grows rapidly that is more than 10 percent the total population of Indonesia that shops through ecommerce platforms, thus may signifies Indonesia as the largest market for the ecommerce industry in Southeast Asia. ${ }^{1}$ This is also proven by the fact that Indonesia's ecommerce growth rate have reached $78 \% .^{2}$ Furthermore, Bank Indonesia recorded ecommerce transactions per February 2021, reached Rp 27.2 trillion, up 45.28\%. ${ }^{3}$ Data from Analytics Data Advertising (ADA) shows a decrease in visits to shopping centers (mall) by $50 \%$, followed by an increase in application usage $300 \%$ online shopping since

\footnotetext{
${ }^{1}$ Ayman Falak Medina, "Indonesia's Law on E-Commerce: Clear Guidelines and Compliance by November 2021," ASEAN Briefing, 2020, https://www.aseanbriefing.com/news/indonesias-law-on-e-commerceclear-guidelines-and-compliance-by-november-2021/.

2 Eddy Cahyono Sugiarto, "Ekonomi Digital The New Face of Indonesia's Economy," KEMENTERIAN SEKRETARIAT NEGARA REPUBLIK INDONESIA, 2019, https://www.setneg.go.id/baca/index/ekonomi_digital_the_new_face_of_indonesias_economy.

3 "BI: Nilai Transaksi e-Commerce Februari 2021 Naik 45,28\%," Kontan.co.id, 2021, https://nasional.kontan.co.id/news/bi-nilai-transaksi-e-commerce-februari-2021-naik-4528.
} 
the social distancing policy was announced on 15 March $^{4}$ that indicates how huge Indonesian market for domestic and foreign e-commerce transactions really is. As consumers in this era, it provides them with an advantage since the market is not limited to only their respective countries, as they are able to conduct a transaction anywhere furthermore there are wide range of options for them to pick according to what they desire while matching their financial conditions. ${ }^{5}$ On the other hand, the legal framework of e-commerce transactions in Indonesia still has some loopholes since is not updated with the recent conditions thus placing consumers in a weak position as business actors may use this to their advantages. ${ }^{6}$ In comparison based on the writer understanding, the United States as a common law country, have provided specific regulations as it is based on jurisprudence and landmark cases which helps decision making in the dispute settlement procedure furthermore, it minimize loopholes to emerge and the regulations are relevant as it is referred to newer cases also there are specific issues that can directly be use as a comparison. In contrast, Indonesia regulates generally thus giving birth to loopholes and confusion on what can be use in safeguarding the consumers. Hereby an update of consumers protection law that is relevant with the recent issues is really needed, since it is through the regulation, where customers can maintain their own rights and fight against harmful business principle of the business actors. Conclusively, that is why it is urgent for this issue to be discussed.

\section{Research Question.}

a. What is required to be amended for Indonesian regulations related to consumer protection be adequate with today's issues in contrast to the United States regulations?

b. What needs to be done regarding the consumer protection organizations in order to safeguard consumers in e-commerce transactions?

c. What suggestion is needed in order to for the legal protection and enforcement to be effective and optimized in securing legal protection in Indonesia?

\section{Research Purpose.}

a. To conduct a comparative analysis research between Indonesian and United States law and underline the differentiation in regards to the consumer protection regulation.

b. To contribute in providing analysis between Indonesian and United States consumer protection organizations in dealing with consumer protection issues faced by the consumers.

\footnotetext{
${ }^{4}$ Ira Aprilianti, "Hari Konsumen Nasional, Perlindungan Data Pribadi Di Tengah Pandemi COVID-19," 2020, https://referensi.elsam.or.id/wp-content/uploads/2020/04/Hari-Konsumen-Nasional-Perlindungan-DataPribadi-di-Tengah-Pandemi-COVID-19.pdf.

5 Shema Hanida Putri, "Dampak E-commerce terhadap Perkembangan Ekonomi Indonesia di Masa Pandemi," 2021, https://www.kompasiana.com/shemahnd/60f1503206310e6da70a24e2/dampak-ecommerce-terhadap-perkembangan-ekonomi-indonesia-di-masa-pandemi.

$6 \mathrm{Ni}$ Putu Trisna Widyantari, A.A. Ngurah Wirasala, "PELAKSANAAN GANTI KERUGIAN KONSUMEN BERKAITAN DENGAN KETIDAKSESUAIAN PRODUK PADA JUAL BELI ONLINE.," Kertha Semaya : Journal IImu Hukum, 53, no. 9 (2019): 4, https://ojs.unud.ac.id/index.php/kerthasemaya/article/view/52247.
} 
c. To analyze on the things Indonesia needs to improve both in regulation and organization in the aim to secure consumer's rights in doing e-commerce transactions.

d. To provide suggestion in supporting the development of consumer protection in Indonesia.

\section{Discussion.}

a. History of Consumer Protection Regulation in Indonesia and United States.

The history of consumer protection law in Indonesia, is inseparable from the sounding of a need in consumer protection movement with the establishment of the non-governmental organization Indonesian Consumers Foundation/Yayasan Lembaga Konsumen Indonesia (YLKI) in May 1973. ${ }^{7}$ Encouraged by the creation of YLKI, in the year 1988, Consumer Development and Protection Institute/Lembaga Pembinaan dan Perlindungan Konsumen (LP2K) was established in Semarang. Moreover, there is Indonesian Consumer Development Foundation/Yayasan Lembaga Bina Konsumen Indonesia (YLBKI) in Bandung and from there it also spreads YLKI representatives in various provinces in Indonesia. ${ }^{8}$ Through the efforts of YLKI, it finally succeeded to brought the UUPK academic text to the House of Representatives/Dewan Perwakilan Rakyat (DPR), which then become the birth of a regulation we know as Law No.8/1999 on consumer protection/Undang-Undang No. 8 Tahun 1999 Tentang Perlindungan Konsumen (UUPK) on April 20, 1999 which acts as the primary centralized basis regulation that regulates consumer protection in Indonesia. ${ }^{9}$

Meanwhile in the United States, it began with the responses of crises and public emergencies that made public outrage awakened with consumer movements which began in the 19th century. In response to that, President Kenedy enacted the Consumer Bill of Rights to safeguard the transactions of unsafe products that results in fraud and bad business practice that violates the rights of consumers. In contrast, United States regulations vary from local, state until national regulations and even incorporating private sectors action rights, also the focus of the law is on the variations, and depth of each issue that is discussed as it is based on each landmark cases, which differs greatly from Indonesia that focuses on single and centralized source of law in regulating issues. Such as the case of United States meat packing industry that disregard the safety of foods which lead to the implementation of Food and Drug Administration and the first regulation related with safety of food in the United States. ${ }^{10}$

\footnotetext{
7 Putri Syahrida, "HUKUM PERLINDUNGAN KONSUMEN," n.d., 19, http://digilib.unila.ac.id/4146/11/bab 2.pdf.

${ }^{8}$ Putri Syahrida, 19.

${ }^{9}$ Putri Syahrida, 20.

10 Spencer Weber Waller, Jillian G. Brady, and R.J. Acosta, "Consumer Protection in the United States: An Overview," 2011,

1, https://www.researchgate.net/publication/228208216_Consumer_Protection_in_the_United_States_An _overview.
} 
b. The Consumer Protection Organizations in Indonesia and United States

Both countries, Indonesia and United States have special organizations that are used to oversee business competition in their respective jurisdiction. The organization that oversees consumer protection in Indonesia is known as the National Consumer Protection Institution/Badan Perlindungan Konsumen Nasional (BPKN) which centralizes to improve the regulation by providing recommendations to the government ${ }^{11}$, helping non-governmental organizations, sharing information in regards to consumer protection. ${ }^{12}$ Other govermental organization is Consumer Dispute Settlement Institution/Badan Penyelesaian Sengketa Konsumen (BPSK). that specializes in receiving and settling consumers complaints and disputes either it is through mediation, arbitration, or conciliation as well as providing consultation, observing the usage of standard contracts, and reporting any infringement of UUPK to the legal authorities if it was observed. ${ }^{13}$ Lastly, there ia also a non-governmental Consumer Protection Organizations/Lembaga Perlindungan Konsumen Swadaya Masyarakat (LPKSM), such as the previously mentioned Yayasan Lembaga Konsumen Indonesia (YLKI), that is behind the birth of UUPK, that have similar purpose like BPKN. ${ }^{14}$

On the other hand, the United States, in the year 1914, the Federal Trade Commission Act (FTCA) was formed and from the creation of FTCA, it created the Federal Trade Commission (FTC) which is tasked with enforcing antitrust law and promoting issues like unlawful business practice done in an online transaction. Besides that, FTC has its own bureau consumer protection which its solely focusing on the investigation process relating to consumer's complaints that is caused due to violations of consumer protection law. ${ }^{15}$ FTC also releases reports and recommendation relating with e-commerce transaction to the public, and also gathering info and investigations related with the business which relates to the company where consumers are doing transaction with. ${ }^{16}$ This organization have two specific goals which are first, to safeguard customers, by aiming to prevent the occurrence of fraud, deception and unfair practice related to business in the market. Second, in creating a fair and competitive market by preventing anticompetitive practice from happening in the marketplace. ${ }^{17}$ Furthermore, there is also another organization called Federal Communications Commission, or "FCC" that aims to encourage the importance of transparency in doing an online transaction as regulated by the requirements of the law. ${ }^{18}$ But per December 11 ,

\footnotetext{
${ }^{11}$ Dewan Perwakilan Rakyat, "Undang-Undang (UU) No. 8 Tahun 1999 Tentang Perlindungan Konsumen" (1999) article 31 and 34(1), https://peraturan.bpk.go.id/Home/Details/45288/uu-no-8-tahun-1999.

12 Dewan Perwakilan Rakyat., article 34(1).

${ }^{13}$ Dewan Perwakilan Rakyat., article 52.

${ }^{14}$ Dewan Perwakilan Rakyat., article 44(3).

15 “Consumer Rights Law," Justia, n.d., https://www.justia.com/consumer/consumer-protection-law/.

16 "Federal Trade Commission Act," Federal Trade Commission, n.d., https://www.ftc.gov/enforcement/statutes/federal-trade-commission-act.

17 Waller, Brady, and Acosta, "Consumer Protection in the United States: An Overview"., 3

18 Law Shelf Educational Media, "Online Consumer Protection in E-Commerce Transactions - Module 3 of 5," n.d., https://lawshelf.com/videocoursesmoduleview/online-consumer-protection-in-e-commercetransactions-module-3-of-5/.
} 
2017, these two organizations enter into a memorandum of understanding and signed formal contract which states that both agencies will cooperate their action to produce a more effective and efficient results which benefits the consumers, where the FCC will now supports in reviewing informal complaints, FTC will helps in doing investigations and enforcement aspects and both will facilitate each other with legal expertise and technicians. ${ }^{19}$

c. The Consumer Protection Regulation and Updates in Indonesia and the United States

Discussing the updates of Indonesia's consumer protection regulation, whereas time progresses, Indonesia adapts by creating more regulation that synchronize with the use of technology nowadays, although it is still very broad and general, like Law No. 11/2008 on Information \& Electronic Transaction/Undang-Undang nomor 11 tahun 2008 tentang Informasi \& Transaksi Elektronik (UU ITE). Where it regulates issues concerning electronic transactions that are based on several purposes and principles, such as benefit, prudence, and good faith ${ }^{20}$ that becomes the foundation of the regulation applied in this regulation. Through the enactment of this regulation it also provide an overview of various aspects affiliated with online transactions, for instance the legality of online documents and digital signatures that have legal force and legal consequences. ${ }^{21}$ Regulation overview of electronic transaction included right and obligations that bind both parties, contractual agreement, and the Electronic Agent Operator. ${ }^{22}$ Prohibited actions that are regulated in the law, alternative dispute resolution methods to settle dispute between parties involve in a transaction, legal criminal sanctions for party that violates the law. ${ }^{23}$

Recently Indonesian government just enacted the Government Regulation No.80/2019 Of Trading Through Electronic Systems/ PP 80 tahun 2019 tentang Perdagangan Melalui Sistem Elektronik (PP PMSE) that governs several issues including first, the party conducting the trading. Second, its requirements and implementation. Third, obligations of business actors. Fourth, proof of electronic trading transactions. Fifth, electronic advertisement. Sixth, electronic offering, acceptance and confirmation in an electronic contract. Seventh, protection of personal data and its payment system and delivery of goods and service through online means. Eighth, exchange of goods or services and cancellation of

\footnotetext{
19 Federal Trade Comission, "FTC, FCC Outline Agreement to Coordinate Online Consumer Protection Efforts Following Adoption of The Restoring Internet Freedom Order," 2017, https://www.ftc.gov/newsevents/press-releases/2017/12/ftc-fcc-outline-agreement-coordinate-online-consumer-protection.

20 Dewan Perwakilan Rakyat, "UNDANG-UNDANG REPUBLIK INDONESIA NOMOR 11 TAHUN 2008 TENTANG INFORMASI DAN TRANSAKSI ELEKTRONIK" (2008), https://www.kpk.go.id/images/pdf/uu pip/UU_ITE no 11 Th 2008.pdf., article 3.

${ }^{21}$ Dewan Perwakilan Rakyat., article 5-12.

22 Dewan Perwakilan Rakyat., article 17-22.

23 Dewan Perwakilan Rakyat., article 27-52.
} 
purchases in electronic transactions. Ninth, dispute resolution, guidance and the supervision for the parties involving with the electronic transactions. ${ }^{24}$

Meanwhile as the United States is a common law country that basis their regulation from landmark cases and jurisprudences, it protects and ensures the consumers rights by enacting various regulations that some of the regulation which is relevant will be discuss in this paper. In the 1980's the organization and congress started thinking of a way in regulating and preventing internet and technological crimes cases. In 1986, the congress then created a law, named the Computer Fraud and Abuse Act, this law prevented others from approaching someone else's computer or its network without the consent or knowing of its owner's permission, so actions such as hacking, cyber theft and destruction or changing of private and classified information of the computer without the knowing or supervision of its owner, are really regulated in order to apply the law enforcement in the aspect of digital and technology. ${ }^{25}$

In 1984 there was a company called CompuServe, at that time the company were still trying to share its product knowledge to the world. But at that time, viruses, spams and worms in computers are just meant to be a prank by most computer engineers, where people at that time did not think it to be something serious and crucial and it attacked the company. Seeing that, U.S government and agencies, decided to make a legal framework in accommodating this computer and computer crime issue which then gave birth to the Computer Fraud and Abuse Act, also known as the CFAA. Later, after the CFAA law finally became effective, it is used to convict a person named Robert Morris, Jr., who is the son of an NSA computer security worker, where he is the one responsible for unleashing the world's first computer virus in the year of $1988 .{ }^{26}$

Truth in Lending Act 1968, which regulates about the principle of lending like transparency in a digital transaction like e-commerce that has amended into The Credit Card Accountability Responsibility and Disclosure Act of 2009 ("Credit CARD Act") which was then enacted on May 21, 2009. ${ }^{27}$ Prior to the creation of this act, consumers which borrow money from lenders at that time face a real hardship in getting a loan, since lenders provided high rates and very long and strict terms of condition in lending their money, to bind them in agreement which totally favors the lenders. Due to that, FTC and the U.S Government take action in creating and enacting the Truth in Lending Act that was purpose solely for protecting consumers in their negotiations with the lenders and creditors, as well as preventing the lenders to create a one-sided terms and condition of agreement

\footnotetext{
24 Dewan Perwakilan Rakyat, "Peraturan Pemerintah (PP) Nomor 80 Tahun 2019 Perdagangan Melalui Sistem Elektronik" (2019), https://peraturan.bpk.go.id/Home/Details/126143/pp-no-80-tahun-2019., article 2 .

${ }^{25}$ Law Shelf Educational Media, "Online Consumer Protection in E-Commerce Transactions - Module 3 of 5."

26 Kim Zetter, "Hacker Lexicon: What Is the Computer Fraud and Abuse Act?," Wired, 2014, https://www.wired.com/2014/11/hacker-lexicon-computer-fraud-abuse-act/.

27 "Obama Signs Credit Card Bill," CBS Interactive Inc., 2009, https://www.cbsnews.com/news/obamasigns-credit-card-bill/.
} 
which only will benefit the lenders while confusing and disadvantaging the borrowers. This act prohibits unsolicited credit cards, regulating the rate mortgage loan standard, set credit card disclosure information, provides notification policy when lenders are going to change the credit card terms and conditions. Also, the consumers can know the actual percentage of mortgage loan, the duration of a loan. On the other hand, this act forces the lenders to provide transparent lending practices to the consumers which borrow their money. ${ }^{28}$

In 2014, a case happened, where this act was used as the legal framework in deciding the court decision. Where the case started with a couple that was currently refinancing their home in February 2007, but the loan agency which they are loaning from, did not explain specifically regarding the notification notice relating to the rescission loan timing of their agreement. Then after 3 years had passed, the couple wrote a letter to the bank which they had made the loan agreement before, stating that they wanted to rescind. The bank told them that their intention cannot be fulfilled. But then this case was brought until the Supreme Court, which then the court gave a verdict that because the couple was never notified about the duration and timing of the rescission by the bank as the lender, so there is no time limit to execute their intention. In the end, the couple's intention of rescission is allowed and the bank, which is the lender, becomes the losing side, since they do not notify the timing of rescission. ${ }^{29}$

Uniform Computer Information Transactions Act (UCITA), this act regulates and provides certainty in legal aspect for consumers doing online transactions such as in licensing of software, online access, and other transactions in computer information. ${ }^{30}$ Uniform Electronic Transactions Act (UETA), was created to simplify writing and signatures required in documents. Uniform Commercial Code (UCC) Article 2B revisions, where this regulation allows contracts to still be enforceable even though it is formed electronically as this helps consumers in maintaining their protection such as protection in purchasing software and online licenses, regulating terms and condition, where consent and contract binding are valid and enforce once consumers has click "I Agree", so it also benefits and safeguard both consumers and business actors. Besides that, there are other specific laws, which regulate these issues more specifically, examples: The Electronic Signatures in Global and National Commerce Act, The Uniform Computer Information Transactions Act; and The Uniform Electronic Transactions Act. ${ }^{31}$

\footnotetext{
28 Ben Halverson, "TILA: An Overview of the Truth in Lending Act," Lorman Education Service, 2019, https://www.lorman.com/resources/tila-an-overview-of-the-truth-in-lending-act-17389.

29 Ben Halverson.

30 "E Commerce," Justia, n.d., https://www.justia.com/business-operations/managing-your-business/ecommerce/.

31 "Laws Pertaining to Commerce on the Internet," Laws office of Stimmel, Stimmel \& Roeser, n.d., https://www.stimmel-law.com/en/articles/laws-pertaining-commerce-internet.
} 
United States Safe Web Act 2006, that provides the Federal Trade Commission the authority to safeguard the consumers in regards to deception and fraud happening in the United States also in cross-border transaction. This act provides the right to FTC in sharing data regarding consumer issues that is currently faced by them, to other countries in ensuring that their rights are still secured even beyond the country's jurisdiction. Moreover, it allows FTC to conduct investigation in other country relating with rights of consumer protection and enforcement. $^{32}$

d. Comparative Analysis Between Indonesian and United States Consumer Protection Law

Comparing the two, it can be analyzed that there are several issues that needs to be improve in regards to the regulations and organizations. First, the legal frameworks are still too general and broad, although Indonesia is a civil law country which primarily based its court ruling on regulations and not landmark cases and jurisprudence, this does not justify those regulations in Indonesia are all regulated broadly, as there is regulation derived from law for instance, government regulations, presidential decrees, local regulations, that actually created to narrowing down the provisions of the law and clarifying things. Nevertheless, it can be seen in various cases that lots of issues are not regulated clearly thus creating a loophole that then used by bad faith parties and thus affected with the consumers.

Center of Indonesian Policy Studies writes, policy frameworks and consumer rights regarding online shopping are still lacking due to the loopholes in the regulations. For instance, in Article 4 of UUPK, it does not regulate regarding data protection and security issues involve in digital transactions, for example regarding privacy policies and not recognize the existence of digital contracts that really affiliates with e-commerce providers, cross-border transactions that have not been discussed as the law only regulates business actors operating within Indonesian jurisdiction although this is the legal basis for consumer protection in Indonesia. ${ }^{33}$ In PP PMSE, even though the government have tried to enact a specialize law that regulated electronic transactions one of the example, it can be seen in the explanation of Article 5 of PP PMSE concerning traders are those who are commercially and still carry out transactions, but the parameters of the commercial and permanent are not clearly explained. ${ }^{34}$

\footnotetext{
${ }^{32}$ Organisation for Economic Co-operation and Development, "DIRECTORATE FOR SCIENCE, TECHNOLOGY AND INNOVATION COMMITTEE ON CONSUMER POLICY Consumer Protection Enforcement in a Global Digital Marketplace," 2018, 23, https://www.oecd.org/officialdocuments/publicdisplaydocumentpdf/?cote=DSTI/CP(2017)10/FINAL\&doc Language $=$ En .

${ }^{33}$ Ira Aprilianti, "[Opini] Hari Konsumen Nasional, Perlindungan Konsumen Online Lemah Di Tengah Pandemi Covid-19," 2020, https://www.cips-indonesia.org/post/opini-hari-konsumen-nasionalperlindungan-konsumen-online-lemah-di-tengah-pandemi-covid-19.

${ }^{34}$ Aisyaa Kay Ashila M. Al Ansharie Y, Faradisa, "Analisis Pro Dan Kontra Dari Peraturan Pemerintah Nomor 80 Tahun 2019 Tentang Perdagangan Melalui Sistem Elektronik," n.d., 9, http://krdfhundip.com/wp-
} 
Most of the specific cases especially related with e-commerce transactions in Indonesia do not have any specific regulation yet to reference to, unlike the United States where they have many specific regulations that can accommodate even the most basic related issue that the consumers faced, so it is the refer and correlate between one case to the other precedent cases that happened prior as it is because that the regulation in the U.S was created based on the landmark cases or issues which they faced specifically at that time.

Besides the regulations there are also organizations. Especially BPKN and BPSK responsible for improving consumer literacy at the local level. However, currently not all regions have the two institutions which impact to the level of consumer literacy and socialization of the existence of consumer protection institutions in the field which creates a lack of consumer knowledge regarding their rights and the institutions responsible for consumer protection thus resulting in the absence of access for consumers to obtain information and obtain advocacy related to their complaints on e-commerce transactions contrast in the United States where the FTC and FCC are continuously developing and socialize issues like this to the consumers. ${ }^{35}$

Lack of consumer knowledge is seen in one of the cases impacting Normal Syah and Tokopedia where consumers rather choose to viral their cases in social media than going to provided institutions. It is a case of selling fake hard disk in Tokopedia uploaded by Norman Syah on Facebook. Where he made a purchase transaction for 2 terabytes Seagate hard disks for 1.6 million Rupiah through Tokopedia e-commerce. But a problem occurs, after he checked, he found out that the hard disk he received is actually a flash disk being covered with a hard disk case that makes the product look as a real hard disk. At first, Norman tried to contact Tokopedia's, but then he received no response. Due to that, Norman decided to announce his case to the public, after it is viral, Tokopedia then contacted and gave support and assistance to Norman and now the seller is being supervised by Tokopedia. ${ }^{36}$

In addition, there is a problem in BPKN authority regulated in article 34 of Consumer Protection Law 1999, as the organization may have the authority in point $F$, to receive complaints about consumer protection, meanwhile there is already BPSK and also YLKI that create a confusion in the field on who really have the authority in receiving and settling consumer's dispute settlement. What should be focused is on the authority to provide recommendations that should be a differentiating factor and special tasks that are managed by BPKN instead of providing overriding authorities that conflicts with BPSK as the primary

\footnotetext{
content/uploads/2020/12/ANALISIS-PRO-DAN-KONTRA-DARI-PERATURAN-PEMERINTAH-NOMOR-80TAHUN-2019-TENTANG-PERDAGANGAN-MELALUI-SISTEM-ELEKTRONIK.pdf.

${ }^{35}$ Aprilianti, "[Opini] Hari Konsumen Nasional, Perlindungan Konsumen Online Lemah Di Tengah Pandemi Covid-19."

36 Norman "Tokopedia," Facebook, 2020, https://www.facebook.com/norman.syah.792/posts/10219829336517942.
} 
organization that is authorize to receive and settle consumer dispute settlements. ${ }^{37}$

Based on the comparative analysis prior, it can be seen that the United States have a more detailed regulations specifically regulating each issue compared to Indonesia that have an overview and general scope that creates overriding and loopholes amongst the regulations and authorities given the consumer protection organizations.

\section{Conclusion and Policy Recommendations}

\section{A. Suggestion}

Based on the explanation previously, several recommendations that can be given in this paper are explain as follows. As stated by Professor Stefan Koos, that one of the things regulators able to do is by creating a system where it is centralized through active information to consumers. This method actually has been implemented by the European Union where they based their regulatory basis on restrictive sanction methods, where it heavily affected by business actors and other parties active in the market to actively inform especially the consumers in regards to violations against consumers rights. As noted by Professor Stefan that the core problem in violation of consumer right is the absence of an effective systematic consumer information that may provide specific information based on prior informed consumer decisions in various situations which then can be applied in other consumers situations as well. This idea is based by the fact that only knowledgeable consumers who are well informed can make the right decision and an effective consumer protection system is actually based of two factors which are legal protection in the violation of consumers right and the active participation of parties in the market to inform the violations happened in the market. ${ }^{38}$

This principle is the same as users report use in Global Positioning System (GPS), where people can make their decisions based on the information provided by other drivers who have passed the route prior. Based on that, this can be implemented into the regulation as it has been done by the European Union, where business actors that have showed good faith and actively providing specific information to consumers may receive restrictive sanction, this way it will indirectly force and increase business actors to give information to consumers and at the same time the violation done by business actors will undoubtedly decrease due to the easiness to report by various parties thus minimizing regulation loopholes as everything will transparent, recorded in digital, verified reports by various parties that will minimize the chance for unlawful parties to occur and also this can increase consumers knowledge.

\footnotetext{
37 Dewan Perwakilan Rakyat, Undang-undang (UU) No. 8 Tahun 1999 tentang Perlindungan Konsumen, article 34 .

38 Stefan Koos, "Artifical Intelligence as Disruption Factor in the Civil Law: Impact of the Use of Artifical Intelligence in Liability, Contracting, Competition Law and Consumer Protection with Particular Reference to the German and Indonesian Legal Situation," Yuridika 36, no. 1 (2021): 257, https://ejournal.unair.ac.id/YDK/article/view/24033/0.
} 
In terms of the general and broad scope of regulation that will cause uncertainties can be minimize by this method, as the consumers may ask question regarding their cases occurred in the field. Moreover, government may also create regulatory review agency to help in reviewing enacted regulations based on cases happened in the field as reported by parties doing transactions and submit it to the constitutional court to conduct a judicial review as creating new and specific regulations is not easy, cheap, need more time and will create more complexity as new regulations appear and may cause more collision and overlapping of regulations in the field that can even make it more difficult for consumers.

Also the government may provide a centralized systematic system through application manage by BPSK and BPKN due to technology advancement and that the user of the application will undoubtedly be the consumers that have transacted in e-commerce so issues relating with lack of technological knowledge will not occur and this may also benefit in terms of control system as complaints will be receive through a single line of submission, and other consumers, business actors and other parties in the market may help in giving active reports of cases that they encountered, where others can just refer to prior submitted case solutions. That way, BPKN and BPSK can focus and work more effective in providing solution for only the new cases that have no precedent case reports.

BPKN can also use the application as a medium to broadcast update information and regulations directly to consumers so the consumers will be well-informed of the new regulations and info that are crucial preventing the violation of their rights. This also helps in dismissing the problem of Indonesian geographical issues and develop BPSK and BPKN to go digital, where now everything does not need to be done offline but jobs can also be done online, and offline methods such as building BPSK office can be primarily focused for regions that does not have internet access yet, this way it may also cut unnecessary cost of operation expenses.

Referring to the loophole in article 34 of BPKN authority that collide with the right of BPSK, the writer recommends, that BPKN should primarily be organization that focuses on giving recommendation to government based on the reports received by BPSK from the consumers complaints, so overlapping authority regulation that will create confusion in consumers on who has the responsibility can be diminished and each organization have a specific goal that they are constantly working on.

As this is a digital transaction it is a must for Indonesia to develop their alternative dispute resolution mechanism into online dispute resolutions to keep up with digitalization and cross-border transactions nowadays. Online dispute resolution itself is a term that indicates the alternative dispute resolution methods regulated in Law No.30/1999 of Arbitration and Alternative Dispute Resolution/UU 30 Tahun 1999 tentang Arbitrase dan Alternatif Penyelesaian Sengketa which is settled through the internet by computers and usage of applications. ${ }^{39}$ In contrast, the United States have applied online dispute resolution through American Arbitration

\footnotetext{
39 Esther van den Heuvel, "ONLINE DISPUTE RESOLUTION AS A SOLUTION TO CROSS-BORDER E-DISPUTES AN INTRODUCTION TO ODR," n.d., 8, https://www.oecd.org/digital/consumer/1878940.pdf.
} 
Association (AAA) which has implemented the ODR into their arbitration procedures that they called Virtual Hearing Managed Service. In short, it is an online arbitration system using zoom video meetings as its medium. ${ }^{40}$ One of the first website in the United States that use the feature of ODR is Cybersettle ${ }^{41}$, that offer ODR consumer settlement relating with payment of insurance claims in the healthcare industry. ${ }^{42}$ Even AAA and Cybersettle have joined in order to further use the facilitation of both ADR and ODR services for their respective consumers. Moreover, this enable their company as one stop service center for both of their clients and even Cybersettle have develop their ODR feature further to online mediation, conciliation and arbitration. ${ }^{43}$ Seeing the rapid development of ODR in the United States, Indonesia must develop their own ODR system that can be implemented and thus result in a more effective and flexible way to settle disputes between parties doing e-commerce transactions.

B. Conclusion

Conclusively, Indonesia has lots of aspect that needs to be improve, starting from the loopholes and overriding in regulations considering the general and broad scope of the law, effectivity of Indonesian regulation outside of country's jurisdiction. Efficiency of governmental and non-governmental organizations in doing their tasks where this heavily affect to consumer trust in settling their disputes rather than making their cases viral by uploading to social media. Increase usage of technology such as online dispute resolution in agencies as compared to the United States. It can be catch up with the urgency of improving the lack of consumer awareness of their own rights and the importance of well-informed consumer in a digital transaction, as now it is already a cross-border transaction that transcends national borders that can be facilitated by governments and parties affiliating in the electronic digital market by using technology to create regulatory review agency, centralized systematic system through application which may help in increasing consumer protection in Indonesia.

\footnotetext{
${ }^{40}$ American Arbitration Association, "Virtual Hearing Managed Services," American Arbitration Association, 2021, https://www.adr.org/virtual-hearing-managed-services.

41 Heuvel, "ONLINE DISPUTE RESOLUTION AS A SOLUTION TO CROSS-BORDER E-DISPUTES AN INTRODUCTION TO ODR."

42 “CyberSettle," n.d., https://www.crunchbase.com/organization/cybersettle.

43 "AAA, Cybersettle, Inc. OK Strategic Alliance," The Metropolitan Corporate Council, 2006, http://www.metrocorpcounsel.com/current_artType_view_artMonth_November_artYear_2006_EntryNo -5922/.
} 


\section{References}

American Arbitration Association. "Virtual Hearing Managed Services." American Arbitration Association, 2021. https://www.adr.org/virtual-hearing-managed-services.

Aprilianti, Ira. "Hari Konsumen Nasional, Perlindungan Data Pribadi Di Tengah Pandemi COVID19," 2020. https://referensi.elsam.or.id/wp-content/uploads/2020/04/Hari-KonsumenNasional-Perlindungan-Data-Pribadi-di-Tengah-Pandemi-COVID-19.pdf.

Aprilianti, Ira. "[Opini] Hari Konsumen Nasional, Perlindungan Konsumen Online Lemah Di Tengah Pandemi Covid-19," 2020. https://www.cips-indonesia.org/post/opini-hari-konsumennasional-perlindungan-konsumen-online-lemah-di-tengah-pandemi-covid-19.

CBS Interactive Inc. "Obama Signs Credit Card Bill," 2009. https://www.cbsnews.com/news/obama-signs-credit-card-bill/.

Comission, Federal Trade. "FTC, FCC Outline Agreement to Coordinate Online Consumer Protection Efforts Following Adoption of The Restoring Internet Freedom Order," 2017. https://www.ftc.gov/news-events/press-releases/2017/12/ftc-fcc-outline-agreementcoordinate-online-consumer-protection.

"CyberSettle," n.d. https://www.crunchbase.com/organization/cybersettle.

Dewan Perwakilan Rakyat. Peraturan Pemerintah (PP) Nomor 80 Tahun 2019 Perdagangan Melalui Sistem Elektronik (2019). https://peraturan.bpk.go.id/Home/Details/126143/ppno-80-tahun-2019.

Dewan Perwakilan Rakyat. Undang-undang (UU) No. 8 Tahun 1999 tentang Perlindungan Konsumen (1999). https://peraturan.bpk.go.id/Home/Details/45288/uu-no-8-tahun-1999.

Dewan Perwakilan Rakyat. UNDANG-UNDANG REPUBLIK INDONESIA NOMOR 11 TAHUN 2008 TENTANG INFORMASI DAN TRANSAKSI ELEKTRONIK (2008). https://www.kpk.go.id/images/pdf/uu pip/UU_ITE no 11 Th 2008.pdf.

Federal Trade Commission. "Federal Trade Commission Act," n.d. https://www.ftc.gov/enforcement/statutes/federal-trade-commission-act.

Halverson, Ben. "TILA: An Overview of the Truth in Lending Act." Lorman Education Service, 2019. https://www.lorman.com/resources/tila-an-overview-of-the-truth-in-lending-act$\underline{17389}$. The Mteropolitan Corporate Council. "AAA, Cybersettle, Inc. OK Strategic Alliance," 2006.

http://www.metrocorpcounsel.com/current_artType_view_artMonth_November_artYear _2006_EntryNo_5922/.

American Arbitration Association. "Virtual Hearing Managed Services." American Arbitration Association, 2021. https://www.adr.org/virtual-hearing-managed-services.

Aprilianti, Ira. "[Opini] Hari Konsumen Nasional, Perlindungan Konsumen Online Lemah Di Tengah Pandemi Covid-19," 2020. https://www.cips-indonesia.org/post/opini-hari-konsumennasional-perlindungan-konsumen-online-lemah-di-tengah-pandemi-covid-19.

- - - "Hari Konsumen Nasional, Perlindungan Data Pribadi Di Tengah Pandemi COVID-19," 2020. https://referensi.elsam.or.id/wp-content/uploads/2020/04/Hari-KonsumenNasional-Perlindungan-Data-Pribadi-di-Tengah-Pandemi-COVID-19.pdf.

Kontan.co.id. "BI: Nilai Transaksi e-Commerce Februari 2021 Naik 45,28\%," 2021. https://nasional.kontan.co.id/news/bi-nilai-transaksi-e-commerce-februari-2021-naik4528. 
Comission, Federal Trade. "FTC, FCC Outline Agreement to Coordinate Online Consumer Protection Efforts Following Adoption of The Restoring Internet Freedom Order," 2017. https://www.ftc.gov/news-events/press-releases/2017/12/ftc-fcc-outline-agreementcoordinate-online-consumer-protection.

Justia. "Consumer Rights Law," n.d. https://www.justia.com/consumer/consumer-protectionlaw/.

"CyberSettle," n.d. https://www.crunchbase.com/organization/cybersettle.

Dewan Perwakilan Rakyat. Peraturan Pemerintah (PP) Nomor 80 Tahun 2019 Perdagangan Melalui Sistem Elektronik (2019). https://peraturan.bpk.go.id/Home/Details/126143/ppno-80-tahun-2019.

- - - Undang-undang (UU) No. 8 Tahun 1999 tentang Perlindungan Konsumen (1999). https://peraturan.bpk.go.id/Home/Details/45288/uu-no-8-tahun-1999.

- - . UNDANG-UNDANG REPUBLIK INDONESIA NOMOR 11 TAHUN 2008 TENTANG INFORMASI DAN TRANSAKSI ELEKTRONIK (2008). https://www.kpk.go.id/images/pdf/uu pip/UU_ITE no 11 Th 2008.pdf.

Justia. "E Commerce," n.d. https://www.justia.com/business-operations/managing-yourbusiness/e-commerce/.

Federal Trade Commission. "Federal Trade Commission Act," n.d. https://www.ftc.gov/enforcement/statutes/federal-trade-commission-act.

Halverson, Ben. "TILA: An Overview of the Truth in Lending Act." Lorman Education Service, 2019. https://www.lorman.com/resources/tila-an-overview-of-the-truth-in-lending-act-17389.

Heuvel, Esther van den. "ONLINE DISPUTE RESOLUTION AS A SOLUTION TO CROSS-BORDER EDISPUTES AN INTRODUCTION TO ODR," https://www.oecd.org/digital/consumer/1878940.pdf.

Kim Zetter. "Hacker Lexicon: What Is the Computer Fraud and Abuse Act?" Wired, 2014. https://www.wired.com/2014/11/hacker-lexicon-computer-fraud-abuse-act/.

Koos, Stefan. "Artifical Intelligence as Disruption Factor in the Civil Law: Impact of the Use of Artifical Intelligence in Liability, Contracting, Competition Law and Consumer Protection with Particular Reference to the German and Indonesian Legal Situation." Yuridika 36, no. 1 (2021): 257. https://e-journal.unair.ac.id/YDK/article/view/24033/0.

Law Shelf Educational Media. "Online Consumer Protection in E-Commerce Transactions Module 3 of 5," n.d. https://lawshelf.com/videocoursesmoduleview/online-consumerprotection-in-e-commerce-transactions-module-3-of-5/.

Laws office of Stimmel, Stimmel \& Roeser. "Laws Pertaining to Commerce on the Internet," n.d. https://www.stimmel-law.com/en/articles/laws-pertaining-commerce-internet.

M. Al Ansharie Y, Faradisa, Aisyaa Kay Ashila. "Analisis Pro Dan Kontra Dari Peraturan Pemerintah Nomor 80 Tahun 2019 Tentang Perdagangan Melalui Sistem Elektronik," n.d., 9. http://krdfhundip.com/wp-content/uploads/2020/12/ANALISIS-PRO-DAN-KONTRA-DARIPERATURAN-PEMERINTAH-NOMOR-80-TAHUN-2019-TENTANG-PERDAGANGAN-MELALUISISTEM-ELEKTRONIK.pdf.

Medina, Ayman Falak. "Indonesia's Law on E-Commerce: Clear Guidelines and Compliance by November 2021." ASEAN Briefing, 2020. https://www.aseanbriefing.com/news/indonesiaslaw-on-e-commerce-clear-guidelines-and-compliance-by-november-2021/. 
Interactive Inc. "Obama Signs Credit Card Bill," 2009. https://www.cbsnews.com/news/obama-signs-credit-card-bill/.

Organisation for Economic Co-operation and Development. "DIRECTORATE FOR SCIENCE, TECHNOLOGY AND INNOVATION COMMITTEE ON CONSUMER POLICY Consumer Protection Enforcement in a Global Digital Marketplace," 2018, 23. https://www.oecd.org/officialdocuments/publicdisplaydocumentpdf/?cote=DSTI/CP(2017) 10/FINAL\&docLanguage=En.

Putri, Shema Hanida. "Dampak E-Commerce Terhadap Perkembangan Ekonomi Indonesia Di Masa Pandemi," 2021. https://www.kompasiana.com/shemahnd/60f1503206310e6da70a24e2/dampak-ecommerce-terhadap-perkembangan-ekonomi-indonesia-di-masa-pandemi.

$\begin{array}{llll}\text { Putri Syahrida. "HUKUM PERLINDUNGAN KONSUMEN," } & \text { n.d., } & 19 .\end{array}$ http://digilib.unila.ac.id/4146/11/bab 2.pdf.

Sugiarto, Eddy Cahyono. "Ekonomi Digital The New Face of Indonesia's Economy." KEMENTERIAN $\begin{array}{lll}\text { SEKRETARIAT NEGARA INDONESIA, } & 2019 .\end{array}$ https://www.setneg.go.id/baca/index/ekonomi_digital_the_new_face_of_indonesias_eco nomy.

Syah, Norman. "Tokopedia." 2020. https://www.facebook.com/norman.syah.792/posts/10219829336517942.

Waller, Spencer Weber, Jillian G. Brady, and R.J. Acosta. "Consumer Protection in the United States: An Overview," 2011, 1. https://www.researchgate.net/publication/228208216_Consumer_Protection_in_the_Uni ted_States_An_Overview.

Widyantari, Ni Putu Trisna; Wirasala, A.A. Ngurah. "PELAKSANAAN GANTI KERUGIAN KONSUMEN BERKAITAN DENGAN KETIDAKSESUAIAN PRODUK PADA JUAL BELI ONLINE." Kertha Semaya: Journal IImu Hukum, 53, no. 9 (2019): 4. https://ojs.unud.ac.id/index.php/kerthasemaya/article/view/52247.

Conflict of Interest Statement: The authors(s) declares that the research was conducter in the absence of any commercial or financial relationship that could be construed as a potential conflict of interest.

Copyright: UARLRey. This is an open access article distributed under the terms of the Creative Commons Attribution 4.0 International Licence (CC-By 4.0 ), which permits unrestricted use, distribution, and reproduction in any medium, provided the orieinal author and source are credited.

UIR Law Review (UIRLRev) is an open access and peer-reviewed journal published by Faculty of Law, Universitas islam Riau; Indonesia. 